its inception in 1887 , partly as the result of a suggestion made in the House of Commons, are manifold and far-reaching. Not only does it serve as the official organ in which the results of scientific activity at $\mathrm{Kew}$ are largely given to the world; it also serves the very important function of placing at the disposal of the economic and scientific gardens in India and the Colonies the latest facts in economic botany that may be of importance to them.

It must be remembered that Kew is the central institution of a great system of smaller institutes established in every region of the Empire, and that these institutes exist to further the material prosperity of the countries in which they are situated. The principal sources of wealth in most of our foreign possessions consist for the most part of vegetable products, and it is difficult to overrate the importance of keeping the botanical stations, remote as they mostly.are from the main channels of current scientific work, continually informed on relevant matters which from time to time reach the great clearing-house at Kew. It must be evident to everyone that any action which tends to lower the efficiency of these institutes of economic botany must operate in a manner detrimental to the material interests of the country or countries thus affected. It is difficult to believe that either the India Office or the Colonial Office, which are both concerned with the functions that only Kew is in a position effectively to discharge, can have been consulted in the matter, or, if they had been so consulted, that they could have approved of a step so unsound alike on economic and financial grounds.

Furthermore, it should not be forgotten that Kew receives a good deal from other countries by way of exchange for the Bulletin, which it is now proposed to suspend. We understand that enemy countries, although their colonial interests are as nothing compared with our own, have, nevertheless, not seen fit to interfere with the continued publication of their own corresponding journals.

In fact, the same official lack of appreciation of the importance of scientific inquiry and research which was a matter of common knowledge amongst our competitors before the war still continues to sap the foundations of our recognised claims to our foreign possessions, which should largely rest on the encouragement of their material development on sound economic, and therefore on scientific, lines.

It is earnestly to be hoped, that the action apparently taken may be reconsidered before we allow ourselves, as a colonial Power, to be made ridiculous, and as a business people to stand committed to the policy of penny wise and pound foolish.

Unless we learn in time the lessons which this war is enforcing on every side, namely, that the way of prosperity in the future lies in promoting scientific knowledge and in utilising the results of scientific investigation, it will make but little difference in the long run whether we win the war or not. For we should assuredly lose in the far more serious conflict that is certain to follow it, a conflict in which the claim for superiority will be inexorably decided against any nation which refuses to take full advantage of that knowledge which is power in a sense far more real than ever before.

J. B. F.

\section{CONSERVATION OF WILD LIFE IN} CANADA.

$\mathrm{IN}$ spite of the energy with which the Canadians are devoting themselves to the prosecution of the war and its successful conclusion, the necessity of conserving our natural resources is not being forgotten. Not the least important of these resources is the wild life of the Dominion. The economic value of the wild life to the country is fully realised by the Canadian Government. On this account it is taking steps to conserve, while it is still able to do so, the wild life upon which many of its economic interests depend. The necessity of greater protection for the species of migratory birds which are important to agriculture as insect destroyers was mainly responsible for the conclusion of the recent international treaty with the United States for the protection of migratory birds in Canada and the United States. This treaty is undoubtedly the most important and farreaching measure ever taken in the history of bird protection. The full text of the treaty and the circumstances responsible for its consummation are given in an article by the present writer in the Agricultural Gazette of Canada for December last. In addition to the protection of insectivorous birds, the treaty provides that no species of migratory wild-fowl, such as ducks, geese, or shorebirds (plovers, sandpipers, etc.), shall have a longer open season than three and a half months, and the open seasons are so restricted as to prevent the killing of the birds in the breeding season. Close seasons for periods of several years are provided for certain species of birds the continued existence of which has become seriously menaced.

In the north-west territories the fur-bearing animals and such larger animals as the barrenground caribou and musk-ox constitute the only available natural resources, and the existence of the present and future populations of large portions of that unorganised territory largely depends on the presence of such wild life. Steps are therefore being taken to ensure the conservation of the northern wild life by improved legislation. In order that this problem may be carefully studied with a view to the adoption of an adequate policy for the protection and use of the wild-life resources of the country, the Canadian Government has recently appointed an inter-departmental Advisory Board on Wild Life Protection, consisting of the following:-Mr. James White, Assistant to the Chairman of the Commission of Conservation (chairman); Mr. D. C. Scott, Deputy-Superintendent of Indian Affairs; Mr. J. B. Harkin, Commissioner of Dominion Parks; Dr. R. M. Anderson, in charge of mammals in the National No. 2482 , VOL. 99] 
Museum; and the present writer, who is secretary of the Board.

The Dominion and Provincial Governments have been active in the establishment of animal parks for the protection of game and non-game mammals and birds, and many thousands of square miles of territory have now been reserved as animal refuges, where hunting is absolutely prohibited.

The successful effort of the Canadian Government in preventing the extermination of the American bison, or buffalo, is noteworthy. The original herd of $75^{\circ}$ buffalo that the Government purchased in the United States in 1907 and placed in a special enclosed buffalo park of 168 square miles at Wainwright, Alberta, has now increased to more than 2400, and altogether above 3000 buffalo are now under Government protection, including the wild herd of about 500 head in the Peace River region south-west of Great Slave Lake. With the view of ascertaining the possibilities of the buffalo in relation to agriculture, the Canadian Department of Agriculture is now carrying on experiments in crossing the buffalo with domestic cattle, as the cross-bred animals, like the buffalo, are so admirably suited to withstand the most rigorous conditions of a northern environment and produce excellent beef and superior robes.

A report published by the Commission of Conservation on the fishes, birds, and game of Canada last year gives an excellent account of the manner in which these problems are being dealt with in Canada. Constituting as Canada does the last stronghold of the big-game animals of the North American continent, it is hoped and believed that we shall be successful in preventing the reduction to the point of extermination of the many forms of wild life of interest and importance alike to the settler, the sportsman, and the zoologist.

\section{Gordon HewitT.}

\section{PROF. JOSEPH RIBAN.}

PROF. JOSEPH RIBAN, honorary professor of the Faculty of Sciences of Paris, who has just died at the ripe age of eighty, was one of a type of French chemists which is fast disappearing. Born at Montpellier, he was originally destined for a career in medicine, but under the influence of Balard, the discoverer of bromine, he was led to interest himself in problems connected with pharmacological chemistry, and took up the study of the toxic principle of redoul (Coriaria myrtifolia), which he found to be a glucoside and named corianmyrtine. His work on the physiological, chemical, and physical properties of the new substance occupied him during the greater part of 1864 , and the results appeared in a couple of memoirs which were published in the Journal de Pharmacie and in the Bulletins of the Chemical Society of Paris. Although he continued to follow medicine, Riban was more and more attracted to chemistry, and his nomination as professor of chemistry and technology at the Ecole Normale of Cluny eventually settled his career. In 1869 he joined his old master Balard at Paris as préparateur of his course at the Collège de France.

The Franco-German War interrupted his chemical studies, and during the siege of Paris he was a zealous collaborator of Alphonse Guérin at the military hospital in the Rue des Récollets. On the termination of hostilities he was able to resume his chemical work, and a number of papers appeared in rapid succession, on the products of the condensation of valeric aldehyde, and on aldehydes condensed by the elimination of water, known as aldanes, on the terpenes and their chlorohydrates, on terebene, and on camphene. Riban's investigations in what is confessedly one of the most intricate and difficult fields of organic chemistry attracted considerable attention at the time of their publication. They gained for him his degree of doctor of physical sciences, and eventually, in 1875 , the Jecker prize. The first samples of synthetic camphor arising out of these researches were shown in the Exhibition of 1878 .

Riban now became associated with Berthelot at the College de France, and was transferred to the Sorbonne, where he became assistant-professor of quantitative chemical analysis. $\mathrm{He}$ practically abandoned inquiry in organic chemistry, devoting himself more particularly to general problems of applied chemistry, especially to questions of hygiene. In addition to his work as director of the analytical laboratories at the Sorbonne, he lectured at the Ecole des BeauxArts, and was named a member of the Conseil d'Hygiène. These various public duties left Riban little time for original research, but he published a number of notes and minor communications on compounds of phosphine and on the decomposition of metallic formates and acetates in presence of water, as well as some papers relating to eudiometry and analytical chemistry. He was an active contributor to the "Encyclopédie Chimique" and to the "Dictionnaire de Chimie," and in I899 published a treatise on electrochemical analysis which enjoyed a considerable reputation.

Riban became a vice-president of the French Chemical Society in 1898 , and a vice-president of the Conseil d'Hygiène in I899. He was a careful, conscientious teacher, distinguished for the clarity and simplicity of his exposition, and a painstaking and accurate experimentalist whose work rests upon a solid and durable foundation.

\section{NOTES.}

THE valuable article on rhubarb which appears elsewhere in the present issue was prepared for the Kere Bulletin, the publication of which has been suspended on the ground of shortage of paper. When we see the waste of paper used in Parliamentary Reports, National Service propaganda, and by Government departments generally, and place this by the side of the amount required for the continued publication of such a periodical as the Kew Bulletin-Imperial in its scope and influence-we begin to despair that our State 